\title{
Focused on earnings management of manufacturing sector in the $\mathrm{V} 4$ region
}

\author{
Pavol Durana ${ }^{1, *}$ \\ ${ }^{1}$ University of Zilina, Faculty of Operation and Economics of Transport and Communications, \\ Department of Economics, Univerzitna 1, 01026 Zilina, Slovakia
}

\begin{abstract}
Research background: Earnings management is global phenomenon of legal manipulation. The number of the examinations related to earnings management in the V4 region has been increased. These international studies identified the manipulation between countries and for different periods of years, but the assessment of individual sectors has been still missing. The article focused on sector manufacturing and its earnings management to gain global view of this issue for this region.

Purpose of the article: The basic purpose and the selected aim of provided study was to detect the status of the activities of earnings management between the enterprises in the V4 region in set sector of the national economies.

Methods: The realized financial study used 1,612 Slovak, Czech, Hungarian, and Polish enterprises from sector " $\mathrm{C}$ " manufacturing. Discretionary accruals were computed by the Modified Jones for the year 2019. One-way Anova was run for this investigation to test delivered hypotheses of the paper. Additionally, Scheffe's procedure was computed to identify significant differences in manipulation of the earnings between individual countries.

Findings \& Value added: The article detected that there was difference between earnings management in the V4 region based on selected sample of enterprises from the sector manufacturing. Post hoc comparisons showed that significant discrepancy in earnings manipulation was between Slovak and Hungarian enterprises in 2019 on one hand. On the other hand, similar approach was between other emerging countries.
\end{abstract}

Keywords: business finance; earnings management; modified Jones model; Visegrad Four; globalization

JEL Classification: $M 48 ; G 30 ; F 60$

\footnotetext{
* Corresponding author: pavol.durana@,fpedas.uniza.sk
} 


\section{Introduction}

The rapid development of increased globalization, Industry 4.0, smart production, open Internet infrastructure, and COVID-19 pandemic are bringing a significant shift from conventional management to the innovations (Majduchova \& Kmety Bartekova, 2020; Valaskova et al., 2020; Bailey et al., 2021; Horvath et al., 2021; Mitchell et al., 2021). The managers from the V4 region use new ways to attract the investors. The modern theories of portfolio support the investors to minimize the portfolio risk and maximize the investment return. The structure of emerging financial markets would become beneficial for the investors (Bhutto et al., 2020). Earnings management is possible method to persuade the investors that the enterprise is suitable investment for their portfolio. That is way earnings management is a widely studied area of legal manipulation of the earnings which provides understanding of managerial behaviour to the investors (Setyoputri \& Mardijuwono, 2020). According to agency theory, managers conduct real activities manipulation and resort to advanced accounting accruals to accomplish financial targets (Roychowdhury, 2006; Majercak et al. 2013a; Khuong et al. 2020). Mentioned method respects current legal standards, uses modern system approaches for optimization, and measures the occurrence of extraordinary events, but the failure cannot be totally excluded (Makka \& Kampova, 2018; Majercak et al. 2013b). Dvorsky et al. (2020) highlight the most important business risks with the business failure (market, financial, and personnel risk). The enterprises will always somehow manage to solve it through insurance, risk avoidance and through creation of financial reserves (Kramolis \& Dobes, 2020). Kampova \& Makka (2018) describe expected effects of economic benefits associated with the implementation of voluntary risk of these enterprises. The studies of Kliestik et al. (2020a); Kliestik et al. (2020b), Gregova et al. (2021) and Siekelova et al. (2021) confirm the existence of earnings management in the V4 region, but these investigations were focused on detecting discrepancies between countries in general, for all sectors. It is necessary to atomize whole economy to individual sectors and identify the differences in earnings management activities between countries individually for every sector. Thus, the main aim of the article is to detect the status of the activities of earnings management between the enterprises in the V4 region in sector " $\mathrm{C}$ " manufacturing of the national economies.

The article was structured as follows. In the introduction, the reason of the research, the importance of the issue of earnings management, and brief literature review were portrayed. Secondly, the structure of the data used and the adequacy of the apparatus of mathematical statistics (parametric One-way Analysis of Variance and Post hoc Scheffe's method) were described to fulfil determined target. Then, the findings of the research were depicted in the results chapter. Discussion compared gained results to similar studies. Finally, the limitation and the possible ways of future research were delivered.

\section{Materials and methods}

To fulfil the given research aim following methodological steps were made:

1. Creation of an origin sample.

The enterprises had to meet these criteria to be involved in the dataset: total assets should be at least 3 million $€$, sales at least 2 million $€$ and net income minimally 100,000 $€$. Together there were chosen 1,612 enterprises from the V4 region. 403 enterprises were selected from each country to have balanced dataset to run One-way Anova. The dataset is created on the base of outputs of the Amadeus database provided by Moody' s analytics 
company Bureau van Dijk. All Slovak, Czech, Hungarian, and Polish enterprises were from the sector " $\mathrm{C}$ " manufacturing.

2. Calculation of discretionary accrual.

The investigation is based on the usage of the accrual-based model. Modified Jones model (1995), introduced by Dechow et al., was run for all enterprises in all countries. This model was proven to be the most relevant in the Visegrad conditions as confirmed in the study of Valaskova et al. (2021a) and Blazek (2021).

$$
\begin{gathered}
\frac{N D A_{i t}}{T A_{\mathrm{t}-1}}=\alpha_{0} \frac{1}{A_{\mathrm{it}-1}}+\alpha_{1} \frac{\Delta R E V_{i t}-\Delta R E C_{i t}}{A_{i t-1}}+\alpha_{2} \frac{P P E_{i t}}{A_{i t-1}}+\varepsilon_{i t} \\
\left(T A_{\mathrm{t}-1}=N D A_{i t}+D A_{i t}\right) ;
\end{gathered}
$$

where

$\begin{array}{ll}N D A_{i t} & \text { non-discretionary accrual in a year } \mathrm{t} ; \\ D A_{i t} & \text { discretionary accrual in a year } \mathrm{t} ; \\ T A_{\mathrm{t}-1} & \text { total accrual in a year } \mathrm{t} ; \\ A_{i t-1} & \text { total assets in a year } \mathrm{t}-1 ; \\ \triangle R E V_{i t} & \text { annual change in revenues in a year } \mathrm{t} ; \\ \triangle R E C_{i t} & \text { annual change in receivables in a year } \mathrm{t} ; \\ P P E_{i t} & \text { long-term tangible assets in a year } \mathrm{t} ; \\ \alpha_{0}, \alpha_{1}, \alpha_{2} & \text { coefficients; } \\ \varepsilon_{i t} & \text { prediction error. }\end{array}$

The model is based on a linear regression model, which presupposes that the discretionary accrual is linearly dependent on the annual change in the value of revenues and receivables and on the value of the long-term tangible assets (lagged by total assets), equation (1). Total accrual (the dependent variable in the regression analyses) is calculated as a sum of annual change in receivables and inventories; annual change in payable accounts and depreciation are then subtracted from this sum. The output of the regression analyses enables the calculation of non-discretionary accrual, using the coefficients of the calculated regression equation in the Modified Jones model, and then the discretionary accrual is determined for individual years as indicated in equation (2).

3. Calculation of annual discretionary accrual.

Annual discretionary accruals were calculated for all Slovak, Czech, Hungarian, and Polish enterprises. Thus, a total number of 1,612 discretionary accruals for the V4 region was created for the year 2019 .

4. Using One-way Analysis of Variance (Anova)

The article detected the status of the activities of earnings management between the enterprises in the V4 region in sector " $\mathrm{C}$ " manufacturing of the national economies. It was searching for significant inequality of mean values (discretionary accruals). Poliak et al. (2021) recommend in these types of research the use of Anova. One-way Anova was used for analysed issue of the earnings management. The equal number of enterprises from each country (403 enterprises per country) was randomly chosen to gain balanced samples. The general linear model would be preferred to Anova if the samples are unbalanced. The verification of the assumptions of Anova was tested. The normal distribution in the individual countries was tested by Kolmogorov-Smirnov test. The assumption of 
homoscedasticity was verified using Levene's test. Then, the analysis allowed formulating the following hypothesis of earnings management of enterprises from Visegrad Four:

$H_{0}$ : There is no significant difference in the activities of earnings management between the enterprises in sector " $C$ " manufacturing in the V4 region.

$H_{1}$ : There is a significant difference in the activities of earnings management between the enterprises in sector " $C$ " manufacturing in the V4 region.

If significant differences in the levels were found using the Anova model, the subsequent multiple comparisons were performed using the Scheffe's post-hoc test to find those pairs of countries in which the mean values of the earnings management differ significantly. All tests were run at significance level of 0.05 .

\section{Results}

The first point of the research was to create the origin samples of 403 enterprises for each country. Then, the discretionary accruals were calculated for these samples by the Modified Jones model for the year 2019. The assumptions of Anova were tested before detecting the discrepancies in earnings management between the countries.

The Kolmogorov-Smirnov test was run to test normality of the samples.

$H_{0}$ : The discretionary accrual which the sample was extracted from follows a normal distribution.

$H_{1}$ : The discretionary accrual which the sample was extracted from does not follow a normal distribution.

Table 1. Test of Normality.

\begin{tabular}{|c|c|c|}
\hline \multicolumn{2}{|c|}{ Country } & Kolmogorov-Smirnov test \\
\cline { 3 - 3 } & Czechia & $p$-value \\
\hline \multirow{3}{*}{$\begin{array}{c}\text { Earnings } \\
\text { management }\end{array}$} & Hungary & 0.124 \\
\cline { 2 - 3 } & Poland & 0.101 \\
\cline { 2 - 3 } & Slovakia & 0.099 \\
\hline
\end{tabular}

Source: own

As the computed $p$-value is greater than the significance level alpha, one cannot reject the null hypothesis $H_{0}$ of normality, based on Table 1 . The hypothesis that discretionary accruals Czech, Hungarian, Polish, and Slovak enterprises are normally distributed was not rejected for all cases.

The Levene's test was run to test homoscedasticity.

$H_{0}$ : The variances of discretionary accruals are equal across all samples of countries (homoscedasticity).

$H_{1}$ : The variances of discretionary accruals are not equal for at least one pair of countries (heteroscedasticity). 
Table 2. Test of Homogeneity of Variances.

\begin{tabular}{|c|c|c|}
\hline \multicolumn{2}{|c|}{ Levene's test } & $\boldsymbol{p}$-value \\
\hline Earnings management & Based on Mean & 0.270 \\
\hline
\end{tabular}

Source: own

As the computed $p$-value is greater than the significance level alpha, one cannot reject the null hypothesis $H_{0}$ of homoscedasticity, based on Table 2. The hypothesis that the variances of discretionary accruals are equal across all Czech, Hungarian, Polish, and Slovak samples of enterprises was not rejected.

The assumptions on normality homoskedasticity for using One-way Anova were confirmed. That is way, the main hypothesis of the article was able to test and was set as follows.

$H_{0}$ : There is no significant difference in the activities of earnings management between the enterprises in sector " $C$ " manufacturing in the V4 region.

$H_{1}$ : There is a significant difference in the activities of earnings management between the enterprises in sector " $C$ " manufacturing in the V4 region.

Table 3. One-way Analysis of Variance.

\begin{tabular}{|c|c|}
\hline Anova & $\boldsymbol{p}$-value \\
\hline Earnings management & 0.004 \\
\hline
\end{tabular}

Source: own

As the computed $p$-value is lower than the significance level alpha, one should reject the null hypothesis $H_{0}$, and accept the alternative hypothesis $H_{1}$, based on Table 3 . There is a significant difference in the activities of earnings management (representing by discretionary accruals) between the enterprises in sector " $\mathrm{C}$ " manufacturing in the V4 region. The detection of specific significant difference was performed by Scheffe's post hoc test.

$H_{0}$ : There is no significant difference in the activities of earnings management between the enterprises in sector " $C$ " manufacturing between selected pairs of countries.

$H_{1}$ : There is a significant difference in the activities of earnings management between the enterprises in sector " $C$ " manufacturing between selected pairs of countries.

As the computed $p$-value is lower than the significance level alpha, one should reject the null hypothesis $H_{0}$, and accept the alternative hypothesis $H_{1}$, based on Table 4 . There was only one pair of countries from the V4 region, between which was confirmed significant difference in the activities of earnings management in sector " $\mathrm{C}$ " manufacturing in. The discrepancy in the year 2019 was detected between Slovak and Hungarian enterprises.

As the computed $p$-value is greater than the significance level alpha, one cannot reject the null hypothesis $H_{0}$, based on Table 4 . In addition to the mentioned differences between Slovakia and Hungary, there is similar approach in earnings management, calculated by discretionary accruals, between enterprises from other countries of analysed region. 
Table 4. Multiple Comparisons of Post Hoc Test.

\begin{tabular}{|c|c|c|}
\hline \multicolumn{2}{|c|}{ Country } & Scheffe's test \\
\cline { 2 - 3 } Czechia & Hungary & $\boldsymbol{p}$-value \\
\cline { 2 - 3 } & Poland & 0.315 \\
\cline { 2 - 3 } & Slovakia & 1.000 \\
\hline \multirow{4}{*}{ Hungary } & Czechia & 0.370 \\
\cline { 2 - 3 } & Poland & 0.315 \\
\cline { 2 - 3 } & Slovakia & 0.275 \\
\hline \multirow{3}{*}{ Sland } & Czechia & $\mathbf{0 . 0 0 4}$ \\
\cline { 2 - 3 } & Hungary & 1.000 \\
\cline { 2 - 3 } & Slovakia & 0.275 \\
\hline \multirow{3}{*}{} & Czechia & 0.416 \\
\cline { 2 - 3 } & Hungary & 0.370 \\
\cline { 2 - 3 } & Poland & $\mathbf{0 . 0 0 4}$ \\
\hline
\end{tabular}

Source: own

\section{Discussion}

The results of analysed issue were discussed to the scientific incentives of the similar studies in this part. Kaldonski \& Jewartowski (2020) detect if enterprises using real earnings management care about taxes. Simonidesova et al. (2021) state based on performed statistical method (Pearson and Spearman correlation coefficient), that there is no demonstrable relationship between selected tax indicators (influencing earnings management) of the V4 countries, in the mining sector. Svabova et al. (2020) use the discriminant analysis to create a model to identify fraudulent enterprises in Slovakia, based on the real data on enterprises that were convicted from misleading financial reporting in connection with tax fraud in the years 2009-2018. The model is inspired by the Beneish model, which is one of the most applied fraud detection methods. Valaskova et al. (2021b) state that the economic recession worsens the capital structure of enterprises in Slovakia and Czechia, especially their debt management related with the earnings management. The study performed a non-parametric One-way analysis of variance (the Kruskal-Wallis test) to determine whether the set of indebtedness ratios is the same across countries, districts, and sizes. Gavurova et al. (2021) add that business duration, management education and sex do not influence managers' attitudes to strategic management and strategic business risks. Kaldonski et al. (2020) investigate whether and how institutional ownership stability influences real earnings management. The article shows that institutional investors holding stable equity stakes play an important monitoring role in reducing real earnings management by managers pressured by capital market forces to "meet or beat" earnings targets. Grabinski \& Wojtowicz (2021) investigate the impact of religiosity on accrual and real earnings management in Polish enterprises. The study finds that Catholicism positively (negatively) influences the level of accrual (real) earnings management. They examine the issue of differences between religiosity and personal faith and highlight the problems related to selecting a proxy for religiosity. The results indicate that a firm's preferred earnings management strategy depends heavily on the values shared by the national community. 


\section{Conclusion}

The aim of article was to detect the status of the activities of earnings management between the enterprises in the V4 region in set sector of the national economies. The research showed that there was difference between earnings management in the V4 region based on selected sample of enterprises from the sector manufacturing. It was detected by One-way Anova. Scheffe's Post hoc test identified that significant discrepancy in earnings manipulation was between Slovak and Hungarian enterprises in 2019, and similar approach was between other analysed countries from Central Europe. The limitation of the study wass the use of equal number of the enterprises for each country because of the running Anova. That is way the results may be extended to running general linear model with unbalanced data set of enterprises from V4 region. Future research may be oriented (despite mentioned investigation) to the analysis of the Baltics region as well.

\section{Acknowledgements}

This research was supported by the Slovak Research and Development Agency-Grant NO. APVV-17-0546: Variant Comprehensive Model of Earnings Management in Conditions of the Slovak Republic as an Essential Instrument of Market Uncertainty Reduction, and the science project VEGA 1/0210/19 Research of innovative attributes of quantitative and qualitative fundaments of the opportunistic earnings modelling which author gratefully acknowledges.

\section{References}

1. Bailey, L., Grupac, M., \& Sosedova, J. (2021). COVID-19 vaccine risk beliefs, perceptions, attitudes, and intentions. Review of Contemporary Philosophy, 20, 81-92.

2. Bhutto, S. A., Ahmed, R. R., Streimikiene, S., Shaikh, S. \& Streimikis, S. (2020). Portfolio investment diversification at global stock market: A cointegration analysis of emerging BRICS(P) Group. Acta Montanistica Slovaca, 25(1), 57-69.

3. Blazek, R. (2021). Creative accounting as a global tool for tax optimization. SHS Web of Conferences, 92, 02007.

4. Dechow, P. M., Sloan, R. G., \& Sweeney, A. (1995). Detecting earnings management. Accounting Review, 70(2), 193-225.

5. Dvorsky, J., Petrakova, Z., \& Fialova, V. (2020). perception of business risks by entrepreneurs according to experience with the business failure. International Journal of Entrepreneurial Knowledge, 8(1), 76-88.

6. Gavurova, B., Cepel, M., Belas, J., \& Dvorsky, J. (2020). Strategic management in SMEs and its significance for enhancing the competitiveness in the V4 countries-a comparative analysis. Management \& Marketing-Challenges For The Knowledge Society, 15(4), 557569.

7. Grabinski, K., \& Wojtowicz, P. (2021). The impact of catholic religion on earnings management: A case of Poland. Journal of International Financial Management \& Accounting.

8. Gregova, E., Smrcka, L., Michalkova, L., \& Svabova, L. (2021). Impact of tax benefits and earnings management on capital structures across V4 countries. Acta Polytechnica Hungarica, 18(3), 221-244. 
9. Horvath, J., Gavurova, B., Bacik, R. \& Fedorko, R. (2021). Identification of uncertainty factors in the consumer behaviour of the new generation of customers at the e-commerce level. Journal of Tourism and Services, 22(12), 168-183.

10. Kaldonski, M., \& Jewartowski, T. (2020). Do firms using real earnings management care about taxes? Evidence from a high book-tax conformity country. Finance Research Letters, 35, 101351.

11. Kaldonski, M., Jewartowski, T., \& Mizerka, J. (2020). Capital market pressure, real earnings management, and institutional ownership stability-Evidence from Poland. International Review of Financial Analysis, 71, 101315.

12. Kampova, K., \& Makka, K. (2018). Economic aspects of the risk impact on the fuel distribution enterprises. In Proceedings of the International Conference Transport Means (pp. 231-235).

13. Khuong, N. V., Liem, N. T., \& Minh, M. T. H. (2020). Earnings management and cash holdings: Evidence from energy firms in Vietnam. Journal of International Studies, 13(1), 247-261.

14. Kliestik, T., Nica, E., Suler, P., \& Valaskova, K. (2020). Innovations in the company's earning management: the case for the Czech Republic and Slovakia. Marketing and Management of Innovations, 18(3), 332-345.

15. Kliestik, T., Valaskova, K., Nica, E., Kovacova, M., \& Lazaroiu, G. (2020). Advanced methods of earnings management: monotonic trends and change-points under spotlight in the Visegrad countries. Oeconomia Copernicana, 11(2), 371-400.

16. Kramolis, J., \& Dobes, K. (2020). Debt as a financial risk factor in SMEs in the Czech Republic. Equilibrium. Quarterly Journal of Economics and Economic Policy, 15(1), 87-105.

17. Majduchova, H., \& Kmety Bartekova, M. (2020). Innovations in the creative industry entities. SHS Web of Conferences, 74, 02009.

18. Majercak, P., Cisko S., \& Majercakova E. (2013). The impact of theory of constraints on the management accounting. In Proceedings of 7 th International Days of Statistics and Economics (pp. 894-904).

19. Majercak, P., Klestik, T., Masarova, G., Buc, D., \& Majercakova E. (2013). System approach of logistic costs optimization solution in supply chain. Nase More, 60(5-6), 9598.

20. Makka, K., \& Kampova, K. (2018). Workplace training within the field of prevention of accident management. In Proceedings of 10th International Conference on Education and New Learning Technology (pp. 3276-3280).

21. Mitchell, K., Grupac, M., \& Zauskova, A. (2021). Ethical management and implementation of COVID-19 immunity passports and vaccination certificates: lawfulness, fairness, and transparency. Linguistic and Philosophical Investigations, 20, 45-54.

22. Poliak, M., Poliakova, A., Svabova, L., Zhuravleva, A., N., \& Nica, E. (2021). Competitiveness of price in international road freight transport. Journal of Competitiveness, 13(2), 83-98.

23. Roychowdhury, S. (2006). Earnings management through real activities manipulation. Journal of Accounting and Economics, 42(3), 335-370.

24. Setyoputri, L. S., \& Mardijuwono, A. W. (2020). The impact of firm attributes on earnings management. Polish Journal of Management Studies, 22(1), 502-512. 
25. Siekelova, A., Belas, J., Podhorska, I., Durana, P. (2021). Accrual-based earnings management: A case study in V4 focusing on mining and quarrying sector. Acta Montanastica, Slovaca, 26(1), 70-83.

26. Simonidesova, J., Kudlova, Z., Lukac, J., Manova, E. \& Culkova, K. (2021). Tax aspects of mining companies in V4 countries. Acta Montanistica Slovaca, 26(1), 35-46.

27. Svabova, L., Kramarova, K., Chutka, J., \& Strakova, L. (2020). Detecting earnings manipulation and fraudulent financial reporting in Slovakia. Oeconomia Copernicana, 11(3), 485-508.

28. Valaskova, K., Adamko, P., Frajtova Michalikova, K., \& Macek, J. (2021). Quo Vadis, earnings management? Analysis of manipulation determinants in Central European environment. Oeconomia Copernicana, 12(3), 631-669.

29. Valaskova, K., Kliestik, T., \& Gajdosikova, D. (2021). Distinctive determinants of financial indebtedness: evidence from Slovak and Czech enterprises. Equilibrium. Quarterly Journal of Economics and Economic Policy, 16(3), 639-659.

30. Valaskova, K., Throne, O., Kral, P., \& Michalkova, L. (2020). Deep learning-enabled smart process planning in cyber-physical system-based manufacturing. Journal of SelfGovernance and Management Economics, 8(1), 121-127. 